\title{
MOTIVASI MANAJEMEN LABA \\ DALAM KAPITALISASI BIAYA RISET DAN PENGEMBANGAN
}

\author{
YUSLI MARIADI \\ Pascasarjana Fakultas Ekonomi dan Bisnis Universitas Brawijaya \\ Jl. Mayjen Haryono 165 Malang \\ No. Telepon: 0819977 75802, email: yusli.mariadi@gmail.com
}

\begin{abstract}
SUTRISNO
Pascasarjana Fakultas Ekonomi dan Bisnis Universitas Brawijaya

J1. Mayjen Haryono 165 Malang, No Telepon:0818272455
\end{abstract}

\section{ROSIDI}

Pascasarjana Fakultas Ekonomi dan Bisnis Universitas Brawijaya Jl. Mayjen Haryono 165 Malang, No Telepon:0811366136

\begin{abstract}
The capitalization of research and development $(R \& D)$ costs is a controversial accounting issue because of the contention that such capitalization is motivated by incentives to manipulate earnings. Indonesian Financial Accounting Standards (SAK) allows for the capitalization of $R \& D$ costs. Based on a sample of manufacturing companies of Indonesia Stock Exchange from 2009 to 2011, this study examines whether companies' decisions to capitalize $R \& D$ costs are affected by earningsmanagement motivations such as earnings smoothing and to avoid violating debtcovenant. In addition, this study aims to show that the capitalization of $R \& D$ costs affects the level of firms' earnings-management. Using a Tobit regression model to test the first and second hypotheses and linear regression model to test third hypotheses, the results show that the companies do capitalize the $R \& D$ costs for earnings-smoothing and reducing the risk of violating debt-covenants purposes. In addition, the results show that the capitalization of $R \& D$ cost affects the level of firms' earnings-management and it is a part of earnings management.
\end{abstract}

Keywords : Earnings Management, Cost Capitalization, R\&D Accounting, Earnings Smoothing, Debt Covenant

\section{PENDAHULUAN}

Riset dan pengembangan merupakan hal yang perlu dilakukan untuk inovasi produk baru maupun pengembangan produk yang sudah ada demi merebut pangsa pasar yang besar.Biaya riset dan pengembangan (research and development cost) yang dikeluarkan 
perusahaan tentu tidak lepas dari kebijakan manajemen perusahaan terutama dalam kebijakan akuntansi yaitu perlakuan akuntansi atas biaya riset dan pengembangan. Terkait dengan perlakuan akuntansi tersebut, masalah yang sangat serius yang dihadapi oleh para regulator, akademisi, dan praktisi adalah penentuan perlakuan akuntansi yang tepat untuk biaya riset dan pengembangan.International Accounting Standards memaparkan akuntansi untuk biaya riset dan pengembangan dalam IAS No. 38 “Intangible Assets"(IASB, 2004). Paragraf 54 dalam standar tersebut menyatakan bahwa tidak ada aset tidak berwujud (intangible asset) yang timbul dari riset (atau dari tahap riset sebuah proyek internal) akan diakui sebagai aset dan biaya riset harus dibebankan dalam laporan laba rugi pada periode terjadinya.

Mengenaibiaya pengembangan,paragraf57 IAS No. 38 menyatakan bahwaaset tidak berwujud yang timbul dari pengembangan (atau dari tahap pengembangan proyek internal) diakuijika,dan hanya jika, suatu entitas dapat menunjukkan hal-hal berikut: (a) kelayakan teknis penyelesaiannya sehingga akan tersedia untuk digunakan atau dijual, (b)bertujuan untuk memperoleh aset tidak berwujud dan menggunakannya atau menjualnya, (c) kemampuannya untuk digunakan atau dijual, (d) bagaimana asettidak berwujud menghasilkan kemungkinan manfaat ekonomis di masa depan(e) ketersediaansumber daya teknis,keuangan, dan lainnya yang memadai untuk menyelesaikan pengembangandan digunakan atau dijual, dan (f)dapat diukur secara andal pengeluaran yang timbul dari aset tidak berwujud selama pengembangannya.

Standar Akuntansi Keuangan (SAK) juga memaparkan biaya riset dan pengembangan yang dinyatakan dalam PSAK No. 19 "Aset Tidak Berwujud" (IAI, 2009). Perlakuan akuntansi biaya riset dan pengembangan dinyatakan dalam PSAK No. 19 yang diadopsi dari IAS No. 38 “Intangible assets”.IAS banyak diadopsi oleh negara-negara di dunia termasuk di Eropa seperti Inggris, Italia, dan Perancis.Markarian, Pozza, \& Prencipe(2008) mengungkapkan bahwa regulasi akuntansi di Italia memperbolehkan adanya fleksibilitas dalam kapitalisasi biaya riset dan pengembangan. Menurutnya, felksibilitas tersebut sama seperti yang diperbolehkan oleh IAS. Begitu pula halnya di Indonesia yang regulasi akuntansinya (SAK) masih banyak mengadopsi IAS.

Kapitalisasi biaya riset dan pengembangan selalu menjadi isu akuntansi yang kontroversial. Para pendukung hasil laporan kapitalisasi menunjukkan bahwa riset dan pengembangan adalah asset berumur panjang yang mempengaruhi profitabilitas masa depan (Ballester, Garcia-Ayuso, \& Livnat, 2003; Sougiannis, 1994).Selain itu,biaya riset dan pengembangan secara positif berhubungan dengan nilaipasar (Sougiannis, 1994) dan 
menghasilkan informasi nilai yang relevan kepada investor (Aboody \& Lev, 1998; Healy, Myers, \& Howe, 2002).

Terlepas dari perdebatan tersebut, adanya fleksibilitas dalam pemilihan metode akuntansi untuk biaya riset dan pengembangan merupakan suatu celah bagi manajer untuk melakukan tindakan-tindakan yang oportunis dimana manajer memilih kebijakan akuntansi yang menguntungkan dirinya atau memaksimalkan kepuasannya.Tindakan ini disebut juga perilaku manajemen laba (earnings management).Manajemen laba yang dilakukan melalui pemilihan metode akuntansi yang sesuai dengan keinginan manajemen untuk mencapai laba yang diinginkan merupakan manajemen laba akrual (accrual earnings management). Misalnya pemilihan metode akuntansi persediaan, penyusutan aset tetap, serta pembebanan atau kapitalisasi suatu biaya yang memiliki manfaat jangka panjang (Cohen \& Zarowin, 2010).Beberapa penelitian menunjukkan bahwa kapitalisasi biaya riset dan pengembanganmerupakan salah satu bentuk dari manajemen laba. Singkatnya, hal iniberarti bahwa perusahaanmengkapitalisasiinvestasi riset dan pengembangan mereka dalamrangka mencapaitargetlaba(Bushee, 1998; Mande, File, \& Kwak, 2000; Perry \& Grinaker, 1994).

Penelitian sebelumnya (seperti Markarian, et al., 2008) meneliti dua dari tiga motif utama dari manajemen laba yaitu perataan laba (income smoothing) dankontrak utang (debt covenant) dalam kapitalisasi biaya riset dan pengembangan.Perataan laba diukur dengan tingkat perubahan profitabilitas sedangkan kontrak utang diukur dengan financial leverage. Hipotesis perataan laba menyatakan bahwa manajer melaporkan laba dari tahun ke tahun secara merata dan mengurangi fluktuasi laba dengan tujuan untuk mengurangi persepsi investor maupun kreditur terhadap ketidak pastian perusahaan (Goel \& Thakor, 2003). Konsep income smoothing menurut Fudenberg \& Tirole (1995) mengasumsikan bahwa investor adalah orang yang menolak risiko. Hal ini dapat dikatakan bahwa laba perusahaan yang tidak normal atau tidak stabil memungkinkan investor menganggap investasi yang akan dilakukan memiliki risiko, sehingga dapat mempengaruhi motivasi investor untuk berinvestasi pada perusahaan tersebut. Dari pihak kreditur, adanya ketidak pastian ini memperbesar risiko terhadap kredit yang diberikan sehingga akan memperbesar biaya modal yang dibebankan kepada perusahaan. Perataan laba juga dilakukan manajer untuk menstabilkan bonus yang mereka terima (Scott, 2009).

Hipotesis kontrak utang didasarkan pada implikasi dari literatur tentang agency theory(Jensen \& Meckling, 1976). Literatur ini menunjukkan bahwa kontrak antara debtholders dan pemilik-manajer mencakup persyaratan yang membatasi perilaku manajemen sehingga dapat mencegah tindakan negatif yang dapat merugikan 
debtholders. Hal tersebut menunjukkan bahwa semakin tinggi penggunaan utang untuk membiayai operasi perusahaan, maka semakin banyak pula perjanjian-perjanjian yang harus dipatuhi dalam kontrak utang tersebut (Duke \& Hunt, 1990; Press \& Weintrop, 1990). Tinggi rendahnya tingkat penggunaan utang tersebut dapat dilihat dari rasio financial leverage perusahaan itu sendiri. Oleh karen itu, financial leverage dapat mencerminkan banyaknya perjanjian yang melekat pada kontrak utang tersebut.

Daley \& Vigeland (1983) meneliti perilaku manajer dalam penerapan metode akuntansi antara mengkapitalisasi dan membebankan pengeluaran untuk riset dan pengembangan mempunyai hubungan dengan variabel kontrak utang dan ukuran perusahaan. Mereka menemukan bahwa pilihan manajer antara mengkapitalisasi biaya riset dan pengembangan berhubungan dengan variabel kontrak utang dan ukuran perusahaan.

Penelitian ini memberikan kontribusi dengan memberikan bukti empiris mengenai motivasi manajemen laba dalam kapitalisasi biaya riset dan pengembangan. Penelitian ini merupakan replikasi dari penelitian yang dilakukan oleh Markarian, et al.(2008) yang telah meneliti motivasi manajemen laba di balik kapitalisasi biaya riset dan pengembangan. Markarian, et al.(2008) berhipotesis bahwa keputusan untuk mengkapitalisasi biaya riset dan pengembangan terkait dengandua motivasi utama: perataan labadan kontrak utang. Hasil multivariate menunjukkan bahwa perusahaan mengkapitalisasi biaya riset dan pengembangan untuk melakukan income smoothing,sementara untuk kontrak utang tidak didukung. Replikasi ini didasarkan adanya kesamaan acuan standar akuntansi yang diterapkan di Italia dengan di Indonesia. Hasil penelitian Markarian, et al.(2008) mengenai kontrak utang berbeda dengan hasil penelitian Daley \& Vigeland (1983) yang menemukan bahwa pilihan manajer antara mengkapitalisasi biaya riset dan pengembangan berhubungan dengan variabel kontrak utang dan ukuran perusahaan.

Motivasi dari penelitian ini adalah untuk membuktikan apa yang ditemukan oleh Markarian, et al.(2008) dengan meneliti perusahaan-perusahaan manufaktur yang terdaftar di Bursa Efek Indonesia dari tahun 2009-2011. Penelitian ini bertujuan untuk mengetahui apakah bukti yang ditemukan Markarian, et al.(2008) di Italia dapat ditemukan juga di Indonesia. Penelitian ini juga bertujuan untuk menemukan bukti hubungan positif antara financial leverage dengan kapitalisasi biaya riset dan pengembangan sesuai dengan hasil penelitian Daley \&Vigeland (1983) yang tidak berhasil dibuktikan oleh Markarian, et al.(2008) serta memberikan bukti adanya pengaruh kapitalisasi biaya riset dan pengembangan terhadap tingkat manajemen laba. 


\section{Telaah Literatur dan Pengembangan Hipotesis}

\section{Akuntansi Biaya Riset dan Pengembagan}

Markarian, et al.(2008) mengungkapkan bahwa regulasi akuntansi di Italia memperbolehkan adanya fleksibilitas dalam kapitalisasi biaya riset dan pengembangan. Menurutnya, felksibilitas tersebut sama seperti yang diperbolehkan oleh IAS. Begitu pula halnya di Indonesia yang regulasi akuntansinya (SAK) masih mengadopsi IAS.Sebelumnya, Akuntansi Biaya Riset dan Pengembangan diatur tersendiri dalam PSAK No. 20, kemudian digabung ke dalam PSAK No. 19 (revisi 2000) mengenai "Aktiva Tidak Berwujud" tanggal 13 Oktober 2000. Perubahan tersebut sejalan dengan perubahan International Accounting Standard (IAS), dimana sebelumnya Biaya Riset dan Pengembangan diatur dalam IAS 9 yang efektif berlaku sejak 1 Januari 1995. Kemudian pada bulan September 1998 digabung ke dalam IAS 38 “Intangible Assets” yang efektif berlaku sejak 1 Juli 1999.

PSAK 19 mendefinisikan riset sebagai penelitian orisinil dan terencana yang dilaksanakan dengan harapan memperoleh pembaruan pengetahuan dan pemahaman teknis atas ilmu yang baru. Sedangkan Pengembangan didefinisikan sebagai penerapan temuan riset atau pengetahuan lainnya pada suatu rencana atau rancangan produksi bahan baku, alat, produk, proses, sistem, atau jasa yang sifatnya baru atau yang mengalami perbaikan yang substansial, sebelum dimulainya produksi komersial atau pemakaian.

Paragraf 36 PSAK 19 mengatur bahwa perusahaan tidak boleh mengakui aset tidak berwujud yang timbul dari riset (atau dari tahap riset pada suatu proyek internal).Pengeluaran untuk riset (atau tahap riset pada suatu proyek internal) diakui sebagai beban pada saat terjadinya.Selanjutnya dalam paragraf 37 PSAK 19 dijelaskan bahwasanya pernyataan ini menganut pandangan bahwa dalam tahap riset pada suatu proyek, suatu perusahaan tidak dapat menunjukkan telah adanya suatu aset tidak berwujud yang akan dapat menghasilkan manfaat ekonomis masa depan. Dengan demikian, pengeluaran untuk riset selalu diakui sebagai beban pada saat terjadinya.

Paragraf 39 mengatur bahwa suatu aset tidak berwujud yang timbul dari pengembangan (atau dari tahap pengembangan pada suatu proyek internal) diakui jika, dan hanya jika, perusahaan dapat menunjukkan semua hal berikut ini: (1) Kelayakan teknis penyelesaian aset tidak berwujud tersebut sehingga aset tersebut dapat digunakan atau dijual; (2) Niat untuk menyelesaikan aset tidak berwujud tersebut dan menggunakannya atau menjualnya; (3) Kemampuan untuk menggunakan atau menjual aset tidak berwujud tersebut; (4) Cara aset tidak berwujud menghasilkan kemungkinan manfaat ekonomis masa depan, 
yaitu antara lain perusahaan harus mampu menunjukkan adanya pasar bagi keluaran aset tidak berwujud atau pasar atas aset tidak berwujud itu sendiri, atau, jika aset tidak berwujud itu akan digunakan secara internal, perusahaan harus mampu menunjukkan kegunaan asset tidak berwujud tersebut; (5) Tersedianya sumber daya teknis, keuangan, dan sumber daya lainnya untuk menyelesaikan pengembangan aset tidak berwujud dan menggunakan atau menjual aset tersebut; (6) Kemampuan untuk mengukur secara andal pengeluaran yang terkait dengan aset tidak berwujud selama pengembangannya.

\section{Perataan Laba (Earnings Smoothing)}

Perataan laba merupakan suatu bentuk manajemen laba yang mencerminkan hasil ekonomi, tidak sebagaimana keadaannya, tetapi merupakan penampilan yang diinginkan manajemen (Fudenberg \& Tirole, 1995). Lebih lanjut dikatakan bahwa perataan labamengandalkan tidak pada pemalsuan atau penyimpangan, tetapi pada peluang luas yang terdapat dalam alternatif prinsip akuntansi yang berterima umum (GAAP) dan penjabarannya.Sasaran utamanya adalah untuk melunakkan variabilitas laba setiap tahunnya, dengan mengalihkan pendapatan dari tahun yang baik ke tahun yang buruk. Hipotesis perataan laba menyatakan bahwa pemilihan kebijakan akuntansi yang dilakukan manajer dikendalikan oleh keinginan mereka untuk mengurangi fluktuasi laba (Fudenberg \& Tirole, 1995). Proses perataan tersebut untuk mengurangi fluktuasi laba dari tahun ke tahun dengan menggeser laba dari periode laba tinggi ke periode laba rendah. Proses ini menjadikan laba pada tahun puncak menjadi lebih rendah dan mengurangi fluktuasi laba (Copeland, 1968).

Mengkapitalisasi biaya, termasuk biaya riset dan pengembangan kemudian mengamortisasikannya akan menghasilkan laba yang lebih stabil dibandingkan dengan expense method. Dari segi profitabilitas, awalnya perusahaan yang melakukan kapitalisasi akan lebih tinggi dibandingkan dengan expense method. Pada tahun-tahun berikutnya, perusahaan yang expense method cenderung lebih tinggi profitabilitasnya, karena terdapat beban amortisasi pada laporan laba rugi di perusahaan yang mengkapitalisasi biaya.

Bukti empiris yang ada sejauh ini umumnya mendukung keberadaan perataan laba (misalnya Chaney, Jeter, \& Lewis, 1998). Untuk tujuan empiris, perataan laba biasanya dikarakteristikkan sebagai kecenderungan manajer untuk memilih kebijakan akuntansi yang menaikkan (menurunkan) laba yang dilaporkan ketika laba periode berjalan yang belum dimanej berada di bawah (di atas) ukuran profitabilitas tahun sebelumnya. Konsisten dengan penelitian sebelumnya (Moses, 1987), penelitian ini menggunakan profitabilitas operasi sebagai target perataan laba.Contoh yang dapat dilakukan adalah dengan membebankan atau 
mengkapitalisasi biaya iklan maupun biaya riset dan pengembangan (Scott, 2009). Namun kadangkala, laba perusahaan akan meningkat seiring dengan adanya tambahan aset perusahaan pada periode tersebut. Oleh karena itu, yang menjadi perhatian dalam perataan laba adalah perubahan profitabilitas perusahaan (Goel \& Thakor, 2003). Pada saat profitabilitas perusahaan menurun dari tingkat profitabilitas tahun sebelumnya, manajer akan berusaha meningkatkan laba dengan mengurangi beban pada periode berjalan. Salah satunya dengan mengkapitalisasi biaya riset dan pengembangan.Begitu pula sebaliknya pada saat prubahan profitabilitas naik. Kapitalisasi biaya riset dan pengembangan merupakan salah satu cara yang paling umum dilakukan manajer dalam melakukan perataan laba (Nelson, Elliot, \& Tarpley, 2003). Dengan kata lain, perubahan tingkat profitabilitas yang negatif memungkinan perusahaan memanfaatkan kapitalisasi biaya riset dan pengembangan untuk meningkatkan laba.Dengan demikian, dapat dirumuskan hipotesis pertama yaitu:

H1 : Terdapat pengaruh negatif perubahan profitabilitas perusahaan terhadap tingkat kapitalisasi biaya riset dan pengembangan.

\section{Kontrak Utang (Debt Covenant)}

Kontrak utangadalah kontrak yang ditujukan pada peminjam oleh kreditur untuk membatasi aktivitas yang mungkin merusak nilai pinjaman dan recovery pinjaman. Sebagian besar kesepakatan utang berisi perjanjian (covenant) yang mengharuskan peminjam memenuhi syarat yang disepakati dalam perjanjian utang (Scott, 2009). Watts \& Zimmerman (1990) mengidentifikasikan perjanjian seperti pembatasan deviden (devidend restriction) dan pembatasan pembelian kembali saham (share repurchase restriction), pembatasan modal kerja (working capital restriction), pembatasan merger (merger restriction), dan pembatasan akuisisi (acquitition restriction), pembatasan investasi (investment restriction), asset disposal restriction, dan future financing restriction merupakan bentuk debt covenant. Restriksi yang berdasarkan angka akuntansi meliputi restriksi pembayaran deviden, mengadakan tambahan utang, mengelola modal kerja, dan investasi pada bisnis lain. Kontrak hutang jangka panjang merupakan perjanjian untuk melindungi pemberi pinjaman dari tindakan-tindakan manajer terhadap kepentingan kreditur, seperti pembagian deviden yang berlebihan, atau membiarkan ekuitas berada di bawah tingkat yang telah ditentukan. Semakin cenderung suatu perusahaan untuk melanggar perjanjian hutang maka manajer akan cenderung memilih prosedur akuntansi yang dapat mentransfer laba periode mendatang ke periode berjalan karena hal tersebut dapat mengurangi risiko. Manajer memilih kebijakan akuntansi yang melaporkan laba lebih tinggi dengan pertimbangan agar tidak terjadi kegagalan tehnik (technical default), 
karena kebanyakan debt covenant menyatakan bahwa peminjam harus memenuhi syarat tertentu selama periode tertentu (Scott, 2009).

Proksi yang paling sering digunakan untuk menguji hipotesis kontrak utang adalah rasio leverage(misalnya Watts \& Zimmerman, 1990). Sejumlah penelitian secara khusus dilakukan untuk menguji apakah rasio leverage dapat diandalkan untuk memproksikan kontrak utang (Duke \& Hunt, 1990; Press \& Weintrop, 1990). Sebagian besar penelitin tersebut mendukung penggunaan rasio leverage.

Hipotesis perjanjian utang menyatakan bahwa manajer perusahaan dengan leverage yang tinggi memiliki dorongan yang kuat untuk membuat keputusan meningkatkan laba, misalnya dalam kasus penelitian ini yaitu memanfaatkan lebih banyak kapitalisasi pada biaya riset dan pengembangan. Kapitaslisasi dapat "merenggangkan" pembatasan dalam perjanjian utang tersebut dengan dua cara. Pertama, jika kontrak utang didasarkan pada pengukuran profitabilitas, maka kapitalisasi dapat meningkatkan laba. Kedua, jika perjanjian utang didasarkan pada rasio total utang terhadap aset, maka kapitalisasi dapat menurunkan rasio ini. Tentu saja, ini benar dengan asumsi bahwa pemberi pinjaman tidak menyesuaikan laba perusahaan dan totoal aset dengan mengabaikan efek dari kapitalisasi (Duke \& Hunt, 1990).

Kontrak utang secara umum melibatkan persyaratan laba akuntansi dan rasio keuangan tertentu (likuiditas dan leverage) dan apabila manajemen melakukan pelanggaran, maka pihak kreditur dapat menjatuhkan sanksi yang pada akhirnya dapat memberatkan pihak perusahaan. Oleh karena itu, manajemen akan selalu mengantisipasi dan berusaha untuk menghindarinya, yaitu dengan mengelola laba akuntansi untuk dapat menghindari kemungkinan terjadinya pelanggaran kontrak utang tersebut. Salah satu cara yang dapat dilakukan yaitu dengan mengkapitalisasi biaya riset dan pengembangan (DeFond \& Jimbalvo, 1994). Dengan kata lain, semakin tinggi tingkat financial leverage perusahaan maka semakin besar kemungkinan perusahaan memanfaatkan kapitalisasi untuk mencapai tingkat laba yang disyaratkan dalam kontrak utang.

Dengan demikian, dapat dirumuskan hipotesisi kedua yaitu:

H2 : Terdapat pengaruh positif financial leverage perusahaan terhadap tingkat kapitalisasi biaya riset dan pengembangan.

\section{Kapitalisasi Biaya R\&D dan Manajemen Laba}

Kapitalisasi merupakan salah satu metode akuntansi untuk biaya riset dan pengembangan disamping pembebanan.Pada kondisi standar akuntansi memberikan fleksibilitas terhadap metode akuntansi yang digunakan, maka perusahaan memiliki 
keleluasaan dalam memilih salah satu dari metode tersebut.Adanya fleksibilitas dalam pemilihan metode akuntansi untuk biaya riset dan pengembangan merupakan suatu celah bagi manajer untuk melakukan tindakan-tindakan yang oportunis dimana manajer memilih kebijakan akuntansi yang menguntungkan dirinya atau memaksimalkan kepuasannya.Tindakan ini disebut juga perilaku manajemen laba (earnings management).

Kapitalisasi biaya riset dan pengembangan merupakan salah satu cara yang paling umum dilakukan manajer dalam melakukan perataan laba (Nelson, et al., 2003). Dapat dikatakan bahwa tingkat kapitalisasi biaya riset dan pengembangan akan mempengaruhi tingkat manajemen laba. Dengan demikian, dapat dirumuskan hipotesisi kedua yaitu: H3 : Kapitalisasi biaya riset dan pengembangan berpengaruh terhadap tingkat manajemen laba.

\section{METODE PENELITIAN}

\section{Model Penelitian}

Model penelitian menggunakan 2 model regresi yang berbeda.Model regresi Tobit digunakan untuk menguji hipotesis 1 dan hipotesis 2 , sedangkan pengujian hipotesis 3 menggunakan regresi linear sederhana.Model Tobit digunakan karena variabel dependen capitalization mengandung data yang dibatasi dan berskala campuran yaitu skala rasio pada saat kapitalisasi dan nominal (nilai 0) apabila tidak ada kapitalisasi.Hal ini sangat berpengaruh terhadap hasil analisa regresi. Jika metode OLS digunakan dengan data tersebut, perhitungan parameter akan cenderung mendekati nol juga dan menjadi tidak signifikan, atau jika menjadi signifikan nilainya mengalami bias (terlalu tinggi atau terlalu rendah), sehingga hasil regresi akan menjadi bias dan tidak konsisten. Secara statistik, model Tobit dapat ditunjukkan sebagai berikut.

$$
\begin{array}{ll}
Y_{i}=\beta_{1}+\beta_{2} X_{i}+\mu_{i} & \text { jika RHS }>0 \\
Y_{i}=0 & \text { selainnya }
\end{array}
$$

dimana RHS = right-hand side atau sisi sebelah kanan yang tidak bernilai 0 (Gujarati, 2003). Dari model regresi Tobit di atas dapat diterapkan pada model regresi yang digunakan pada penelitian ini sebagai berikut.

Capitalization $_{i}=\beta_{1}+\beta_{2}$ ChROA $_{i}+\beta_{3}$ Leverage $_{i}+\beta_{4}$ Logassets $_{i}+u_{i t} \quad$ jika RHS > 
selainnya

dimana:

Capitalization $=$ total biaya riset dan pengembangan yang dikapitalisasi (bersih) dibagi dengan total aset perusahaan. Perusahaan yang tidak melakukan kapitalisasi (melakukan pembebanan) biaya riset dan pengembangan diberi angka 0 (nol).

ChROA

$$
=
$$

perubahan ROA (sebelum

kapitalisasi) dari ROA tahun sebelumnya.

Leverage $\quad=$ total utang dibagi total aset (sebelum kapitalisasi).

Logassets $\quad=$ hasil log dari total aset perusahaan pada posisi akhir tahun.

$b_{0} \quad=$ konstanta

$b_{1}-b_{3} \quad=$ koefisien regresi

$u \quad=$ error $\quad$ (Markarian, et al., 2008).

Pengujian hipotesis 3 menggunakan regresi linear sederhana dengan meregresi kapitalisasi biaya riset dan pengembangan terhadap discretionary accruals.Nilai discretionary accruals yang diperoleh dari pengukuran dicretionry accruals, dimasukkan ke dalam model regresi dengan variabel independen Kapitalisasi biaya riset dan pengembangan. Analisis dilakukan dengan regresi linear sederhana yang ditunjukkan dengan model sebagai berikut.

$$
D A_{t}=\alpha_{0}+\alpha_{1} \text { Kapitalisasi }_{t}+\mu_{t}
$$

dimana:

DA $\quad=\quad$ Discretionari Accruals sebagai proksi manajemen laba

Kapitalisasi $\mathrm{t}_{\mathrm{t}}=$ Jumlah biaya riset dan pengembangan yang dikapitalisasi oleh perusahaan.

$\mu_{\mathrm{t}} \quad=\quad$ Error

Analisis regresi ini bertujuan untuk membuktikan bahwa kapitalisasi biaya riset dan pengembangan berpengaruh terhadap tingkat manajemen laba yang diproksikan dengan discretionary accruals dengan melihat nilai koefisien determinasi yang disesuaikan (adjusted $R$-squared) dari regresi tersebut.

\section{Operasionalisasi Variabel}

\section{Kapitalisasi Biaya Riset dan Pengembangan}

Kapitalisasi merupakan jumlah biaya riset dan pengembangan yang dikapitalisasi oleh perusahaan yang masuk dalam aset perusahaan.Variabel kapitalisasi biaya riset dan pengembangan (kapitalisasi) diproksikan dengan rasio kapitalisasi. Rasio kapitalisasi diperoleh dengan membagi total biaya riset dan pengembangan yang dikapitalisasi (bersih) dengan total aset perusahaan. Perusahaan yang tidak melakukan kapitalisasi (melakukan pembebanan) biaya riset dan pengembangan diberi angka 0 (nol). 


\section{Manajemen Laba Akrual}

Variabel manajemem laba digunakan pada analisis regresi linear sederhana untuk pengujian hipotesis 3.Manajemen laba diproksikan dengan discretionary accruals.Discretionary accruals menunjukkan tingkat pengelolaan laba yang dilakukan oleh manajer. Pengukuran dilakukan dengan menggunakan model Jones (1991) yang dimodifikasi oleh Dechow et al. (1995) atau sering disebut juga dengan the modified Jones Model. Model Jones yang dimodifikasi ini memperhitungkan akrual non diskresioner lain yaitu perubahan piutang $(\triangle \mathrm{REC})$ yang tidak diperhitungkan dalam model Jones. Model Jones yang dimodifikasi ditunjukkan dengan model sebagai berikut.

$$
\begin{aligned}
& T A_{t}=\alpha_{0}+\alpha_{1}\left(1 / A_{t-1}\right)+\alpha_{2}\left(\Delta R E V_{t}-\Delta R E C_{t}\right)+\alpha_{3} P P E_{t}+\mu_{t} \\
& T A_{t}=N D A_{\mathrm{i}}+D A_{i} \ldots \ldots \ldots \ldots \ldots \ldots \ldots \ldots \ldots \ldots \ldots \ldots \ldots \ldots \ldots \ldots \ldots \ldots \ldots \ldots \ldots \ldots \ldots \ldots \ldots \ldots \ldots \ldots \ldots \ldots \ldots \ldots \ldots \ldots \ldots \\
& N D A_{t}=\alpha_{1}\left(1 / A_{t-1}\right)+\alpha_{2}\left(\Delta R E V_{t}-\Delta R E C_{t}\right)+\alpha_{3} P P E_{t} \ldots \ldots \ldots \ldots \ldots
\end{aligned}
$$

dimana:

$\mathrm{TA}_{\mathrm{t}}=$ Total akrual tahun $\mathrm{t}$

$\mathrm{A}_{\mathrm{t}-1}=$ Total aset tahun sebelumnya ( $\left.\mathrm{t}-1\right)$

$\triangle \mathrm{REV}_{\mathrm{t}}=\quad$ Perubahan penjualan/pendapatan dari tahun sebelumnya

$\triangle \mathrm{REC}_{\mathrm{t}}=\quad$ Perubahan piutang usaha dari tahun sebelumnya

$\mathrm{PPE}_{\mathrm{t}}=$ Property, Plant, and Equipment (aset tetap) yang digunakan untuk operasi perusahaan

$\mathrm{DA}_{\mathrm{t}}=$ Discretionary Accruals sebagai proksi manajemen laba

$\mathrm{NDA}_{\mathrm{t}}=\quad$ Non-Discretionary Accruals

$\mu_{\mathrm{t}} \quad=\quad$ Error

Model (1) menunjukkan model regresi 1/total aset, selisih antara perubahan pendapatan dan piutang usaha serta aset tetap untuk mendapatkan besarnya nilai estimasi yang dapat digunakan untuk mengestimasi besarnya nilai NDA pada model (3). Model (2) menunjukkan bahwa total akrual terbagi menjadi Non-Discretionary Accruals (NDA) dan Discretionary Accruals (DA). Total akrual sendiri diperoleh dari selisih antara laba operasi dengan kas bersih yang diperoleh dari operasi (operating cash flow).

\section{Perubahan Profitabilitas}

Return on Assets (ROA) sebagai pengukur profitabilitas perusahaan karena ROA menggambarkan sejauh mana tingkat pengembalian dari seluruh aset yang dimiliki perusahaan.Pengukuran kinerja keuangan perusahaan dengan ROA memiliki keuntungan yaitu ROA merupakan pengukuran yang komprehensif dimana seluruhnya mempengaruhi laporan keuangan yang tercermin dari rasio ini (Markarian et al., 2008). ROA dan ChROA dirumuskan sebagai berikut: 


$$
\begin{aligned}
& \text { ROA }=\frac{\text { Laba bersih }}{\text { Total Aset }} \\
& \text { ChROA }=\text { ROA }_{\mathrm{t}}-\mathrm{ROA}_{\mathrm{t}-1} \\
& \text { Keterangan: } \\
& \begin{array}{l}
\text { ROA } \\
\text { ChROA }
\end{array} \quad=\text { Return on Assets } \\
& \begin{array}{ll}
\text { ROA }_{\mathrm{t}} & =\text { Return on Assets tahun berjalan } \\
\text { ROA }_{\mathrm{t}-1} & =\text { Return } \text { on Assets tahun sebelumnya }
\end{array}
\end{aligned}
$$

\section{Financial Leverage}

Proksi yang paling sering digunakan untuk menguji hipotesis kontrak utang adalah rasio financial leverage (misalnya, Hunt, 1985; Watts dan Zimmerman, 1990). Financial leverage diperoleh dengan membagi total utang dengan total aset (sebelum kapitalisasi biaya riset dan pengembangan) perusahaan.

\section{Ukuran Perusahaan (Variabel Kontrol)}

Variabel ukuran perusahaan diproksikan dengan total aset perusahaan dan diukur dengan logaritma natural dari total aset tersebut (Logasset) seperti yang digunakan oleh Daley dan Vigeland (1983) serta Markarian et al. (2008).

\section{Metode Pengumpulan data}

Metode pengumpulan data yang digunakan adalah metode dokumentasi atau disebut juga metode arsip (archival research) yaitu pengumpulan data melalui buku-buku atau dokumen tertulis yang dihasillkan oleh instansi yang berkaitan dengan penelitian.Dalam hal ini dikumpulkan data laporan keuangan perusahaan manufaktur yang diterbitkan oleh BEI yang dapat diunduh melalui alamat web resmi BEI yaitu www.idx.co.id.Arsip yang diperoleh dari situs tersebut berupa laporan keuangan auditan yang terdiri dari neraca, laporan laba rugi, laporan arus kas, laporan perubahan ekuitas, catatan atas laporan keuangan, serta laporan auditor independen.Dari laporan keuangan tersebut, dapat diambil data-data yang dapat digunakan untuk menguji hipotesis berupa laba, total aset, total utang, serta biaya riset dan pengembangan yang dikapitalisasi maupun yang dibebankan.

\section{Populasi dan Sampel}


Populasi yang digunakan adalah perusahaan-perusahaan industri manufaktur yang terdaftar di Bursa Efek Indonesia dari tahun 2009 sampai dengan 2011.Pertimbangan pemilihan perusahaan industri manufaktur adalah homogenitas dalam aktivitas operasi utama serta untuk menghindari bias karena perbedaan industri. Selain itu juga karena sebagian besar perusahaan publik di Indonesia merupakan perusahaan yang bergerak di bidang manufaktur. Sekaran dan Bougie (2010) menunjukkan bahwa kelompok populasi terdiri dari kumpulan orang, hal, atau kejadian yang memiliki karakteristik yang sama. Pertimbangan lain juga karena perusahaan-perusahaan manufaktur memiliki kegiatan usaha yang lebih kompleks dibandingkan dengan perusahaan jenis industri lainnya. Hal ini memunculkan dugaan peneliti bahwa perusahaan-perusahaan industri manufaktur menginvestasikan relatif lebih besar dalam riset dan pengembangan dibandingkan dengan perusahaan jenis industri lainnya.BEI dipilih karena adanya kemudahan memperoleh data yang dibutuhkan sehingga mempermudah proses penelitian. Selain itu juga, perusahaan-perusahaan yang terdaftar di BEI relatif cukup mewakili perusahaan-perusahaan yang ada di Indonesia.

Metode pemilihan sampel yang digunakan adalah nonprobabilitas (nonprobability) dengan pemilihan sampel bertujuan (purposive sampling).Penelitian ini menggunakan judgement sampling dengan mempertimbangkan kriteria-kriteria sebagai berikut: (1) Perusahaan manufaktur yang terdaftar di Bursa Efek Indonesia tahun 2009 sampai dengan 2011. (2) Tersedia laporan tahunan auditan lengkap per 31 Desember tiap tahun penelitian dan tahun sebelumnya. (3) Memiliki data biaya riset dan pengembangan.

Dari kriteria pemilihan sampel di atas, maka diperoleh jumlah sampel sebagai berikut:

Tabel 1

Jumlah Sampel Penelitian

\begin{tabular}{lc}
\hline \multicolumn{1}{c}{ Keterangan } & $\begin{array}{c}\text { Jumlah Perusahaan } \\
\text { Tahun }\end{array}$ \\
\hline $\begin{array}{l}\text { Perusahaan manufaktur yang terdaftar di BEI tahun } \\
\text { 2009 sampai dengan 2011 }\end{array}$ & 387 \\
\hline $\begin{array}{l}\text { Tidak tersedia laporan keuangan auditan lengkap } \\
\text { per 31 Desember tiap tahun penelitian dan tahun } \\
\text { sebelumnya }\end{array}$ & $(40)$ \\
\hline Tidak memiliki data biaya riset dan pengembangan & $(205)$ \\
\hline Jumlah sampel & 142 \\
\hline
\end{tabular}

Metode Analisis

Pengujian Hipotesis 1 dan Hipotesis 2 


\section{Tabel 2}

\section{Statistik Deskriptif Data Variabel}

\begin{tabular}{lcllcc}
\hline \multicolumn{1}{c}{ Variabel } & $\mathrm{n}$ & \multicolumn{1}{c}{ Mean } & \multicolumn{1}{c}{ Min. } & \multicolumn{1}{c}{ Max. } & SD \\
\hline Capitalization & 142 & 0,004 & 0,000 & 0,038 & 0,008 \\
ChROA & 142 & 0,029 & $-0,164$ & 1,221 & 0,100 \\
Leverage & 142 & 0,546 & 0,074 & 2,788 & 0,437 \\
Aset & 142 & 9.207 miliar & 69 miliar & 153.521 miliar & 20.357 miliar \\
\hline
\end{tabular}

Tabel 3

Korelasi Bivariat

\begin{tabular}{cccc}
\hline & ChROA & FL & SIZE \\
\hline ChROA & 1,000 & 0,465 & $-0,065$ \\
FL & 0,465 & 1,000 & $-0,160$ \\
SIZE & $-0,065$ & $-0,160$ & 1,000 \\
\hline
\end{tabular}

Tabel 4

Analisis Hasil Regresi Tobit

Capitalization $_{i}=\beta_{1}+\beta_{2}$ ChROA $_{i}+\beta_{3}$ Leverage $_{i}+\beta_{4}$ Logassets $_{i}+u_{i t} \quad$ jika RHS > $=0$ selainnya

Variabel dependen : Capitalization

\begin{tabular}{lccc}
\hline \multicolumn{1}{c}{ Parameter } & Koefisien Regresi & $t$ statistik & Probabilitas $(\rho)$ \\
\hline Intercept & $-0,008$ & $-0,534$ & 0,593 \\
ChROA & $-0,042$ & $-2,479$ & 0,013 \\
Leverage & 0,009 & 2,112 & 0,035 \\
Logassets (SIZE) & 0,001 & 0,057 & 0,954
\end{tabular}

Tabel 2 menyajikan statistic deskriptif data variabel penelitian, menunjukkan bahwa variabel capitalization memiliki nilai rata-rata sebesar 0,004 yang berarti bahwa secara umum perusahaan sampel mengkapitalisasi biaya riset dan pengembangan sebesar $0,4 \%$ dari total aset. Kapitalisasi terendah sebesar $0 \%$ menunjukkan bahwa dari perusahaan sampel juga terdiri dari perusahaan yang tidak melakukan kapitalisasi terhadap biaya riset dan pengembangan. Kapitalisasi tertinggi yaitu sebesar 3,4\% dari total aset perusahaan. Dari hasil pengumpulan data juga didapatkan jumlah observasi yang melakukan kapitalisasi biaya riset dan pengembangan sebanyak 68 sedangkan yang tidak melakukan kapitalisasi sebanyak 74 observasi.

Perubahan profitabilitas (ChROA) sebesar 0,029 menunjukkan bahwa secara umum perusahaan sampel merupakan perusahaan yang profitable yang ditunjukkan oleh kenaikan 
ROA sebesar 2,9\% dari tahun sebelumnya. Penurunan ROA terbesar yaitu sebesar $16,4 \%$ dari tahun sebelumnya dan kenaikan ROA tertinggi yaitu sebesar 122,1\% dari ROA tahun sebelumnya.

Rata-rata perusahaan sampel memiliki tingkat utang yang tinggi yang ditunjukkan oleh rasio financial leverage rata-rata sebesar 0,546 atau sebesar 54,6\% dari total aset perusahaan. Hal ini meunjukkan bahwa secara umum lebih dari separuh aset perusahaan didanai dari utang, bahkan terdapat perusahaan yang memiliki utang 278,8\% dari total aset (nilai maksimum leverage sebesar 2,788). Leverage terendah yaitu sebesar 0,074 atau sebesar $7,4 \%$ dari total aset perusahaan. Total aset perusahaan sampel yang tertinggi senilai $\mathrm{Rp}$ 153.521 miliar sedangkan yang terendah senilai Rp 69 miliar. Rata-rata perusahaan memiliki total aset senilai Rp 9.207 miliar.

Dari Tabel 3 dapat dilihat bahwa koefisien korelasi bivariat antar variabel independen tidak terdapat nilai koefisien yang melebihi rule of thumb 0,7. Dapat disimpulkan bahwa tidak terdapat multikolinearitas pada data pengamatan.

Dari tabel 4 dapat diketahui bahwa ChROA memiliki nilai estimasi negatif yaitu sebesar $-0,042$ dan signifikan pada $\alpha=5 \%$ dengan nilai $\rho$ sebesar $0,013(<0,05)$. Hasil ini mengindikasikan bahwa semakin tinggi (semakin rendah) profitabilitas dari profitabilitas tahun sebelumnya, maka semakin kecil (semakin besar) jumlah biaya riset dan pengembangan yang dikapitalisasi.

Hasil ini sejalan dengan hasil penelitian sebelumnya yaitu Markarian, et al. (2008)yang menemukan adanya hubungan negatif antara kapitalisasi biaya riset dan pengembangan dengan perubahan profitabilitas. Perusahaan manufaktur yang terdaftar di Bursa Efek Indonesia melakukan kapitalisasi biaya riset dan pengembangan terdapat motivasi manajemen laba untuk meratakan laba dari tahun ke tahun.

Penelitian Kustono (2008)juga menemukan adanya praktik perataan laba pada perusahaan manufaktur yang terdaftar di Bursa Efek Indonesia. Perataan laba merupaka upaya rekayasa berkelanjutan pada beberapa periode. Proses perataan tersebut untuk mengurangi fluktuasi laba dari tahun ke tahun dengan menggeser laba dari periode laba tinggi ke periode laba rendah. Proses ini menjadikan laba pada tahun puncak menjadi lebih rendah dan mengurangi fluktuasi laba (Copeland, 1968).

Selain itu juga Yusuf \& Soraya (2004) menemukan adanya perataan laba yang dilakukan oleh sebagian perusahaan yang terdaftar di Bursa Efek Jakarta, baik perusahaan asing maupun non asing. Penelitian mereka menunjukkan bahwa profitabilitas (menggunakan ROA) perusahaan asing dan non asing yang melakukan praktik perataan laba cenderung 
stabil dari pada perusahaan yang tidak melakukan praktik perataan laba yang cenderung berfluktuasi. Stabilnya profitabilitas pada perusahaan perata laba diduga karena adanya tindakan manipulasi laba yang dilakukan manajemen untuk mengurangi fluktuasi dari laba yang dilaporkan dan meningkatkan kemampuan investor untuk meramalkan kas di masa yang akan datang.

Mengkapitalisasi biaya, termasuk biaya riset dan pengembangan kemudian mengamortisasikannya akan menghasilkan laba yang lebih stabil dibandingkan dengan expense method. Dari segi profitabilitas, awalnya perusahaan yang melakukan kapitalisasi akan lebih tinggi dibandingkan dengan expense method. Pada tahun-tahun berikutnya, perusahaan yang expense method cenderung lebih tinggi profitabilitasnya, karena terdapat beban amortisasi pada laporan laba rugi di perusahaan yang mengkapitalisasi biaya.

Dari tabel 4 juga dapat dilihat bahwa leverage memiliki nilai estimasi positif sebesar 0,009 dan signifikan pada $\alpha=5 \%$ dengan nilai $\rho$ sebesar 0,035 , mengindikasikan bahwa semakin tinggi (semakin rendah) rasio penggunaan utang terhadap total aset, maka semakin besar (semakin kecil) jumlah biaya riset dan pengembangan yang dikapitalisasi. Hasil ini berbeda dengan hasil penelitian Markarian,et al.(2008), namun sesuai dengan yang telah diprediksikan pada hipotesis 2 dan penelitian Daley \& Vigeland (1983) serta Sjarief (2004) yang menemukan bahwa pilihan manajer antara mengkapitalisasi biaya riset dan pengembangan atau tidak, berhubungan dengan variabel kontrak utang. Dengan hipotesis yang sama, Markarian,et al.(2008) tidak berhasil membuktikan dugaan mereka. Hal tersebut disebabkan karena adanya strukturisasi pada perjanjian (kontrak) utang sehingga perusahaan tidak termotivasi untuk mengkapitalisasi biaya sebagai cara untuk menghindari pelanggaran kontrak.

Hal berbeda ditunjukkan oleh hasil penelitian ini, dimana financial leverage berpengaruh positif dan signifikan terhadap tingkat kapitalisasi. Perbedaan ini dikarenakan adanya perbedaan mekanisme dan tingkat pengawasan dari institusi finansial yang berwenang terhadap perusahaan. Di Italia menurut Markarian,et al.(2008)terdapat adanya fakta bahwa institusi finansial cenderung untuk menyesuaikan laba laporan dengan mengeliminasi efek dari adanya kapitalisasi biaya dengan tujuan untuk mengurangi risiko manipulasi yang menyesatkan. Di Indonesia, kondisi tersebut berbeda. Menurut Kustono (2008) mekanisme pengawasan oleh kreditur tidak terbukti di perusahaan publik non keuangan yang terdaftar di Bursa Efek Indonesia. Penyebabnya mungkin pengguna laporan keuangan tidak melihat perataan sebagai sesuatu yang merugikan. Penelitian Kustono (2008) menunjukkan bahwa perataan penghasilan tidak memiliki pengaruh terhadap nilai perusahaan. Hal ini 
mengindikasikan ketidakpedulian pasar terhadap praktik manajemen laba yang dilakukan manajemen.Perataan penghasilan memampukan manajer untuk menurunkan estimasi mengenai volatilitas laba sehingga menurunkan kemungkinan bangkrut.Manajemen memiliki kesempatan untuk memperoleh pinjaman dengan bunga rendah sehingga menurunkan biaya modal.Penurunan biaya modal berkaitan dengan risiko persepsian pemberi pinjaman.Semakin tinggi risiko yang dihadapi maka biaya utang juga semakin meningkat. Salah satu cara untuk menurunkan risiko persepsian adalah dengan menciptakan laba yang stabil.

Mengenai variabel kontrol ukuran perusahaan (logassets), tabel 4 menunjukkan nilai estimasi yang sangat kecil yaitu sebesar 0,001 dan tidak signifikan pada level $\alpha=5 \%$ maupun $\alpha=10 \%$ dengan probabilitas sebesar 0,954 . Hasil tersebut menunjukkan bahwa ukuran perusahaan tidak mempengaruhi keputusan perusahaan untuk mengkapitalisasi biaya riset dan pengembangan. Hal ini kemungkinan disebabkan karena perusahaan manufaktur yang terdaftar di Bursa Efek Indonesia baik perusahaan besar maupun relatif kecil mengkapitalisasi biaya riset dan pengembangan bukan termotivasi oleh political cost, namun lebih kepada tujuan menstabilkan laba akuntansi. Hasil ini mendukung hasil penelitian Markarian,et al. (2008) yang tidak menemukan adanya hubungan antara ukuran perusahaan dengan kapitalisasi biaya riset dan pengembangan. Apabila ukuran perusahaan dikaitkan dengan manajemen laba secara keseluruhan, mungkin ukuran perusahaan akan berpengaruh terhadap manajemen laba seperti yang ditunjukkan oleh Siregar \& Utama (2006) yang menemukan bahwa variabel ukuran perusahaan secara konsisten mempunyai pengaruh negatif yang signifikan terhadap besaraan pengelolaan laba yang dilakukan perusahaan, artinya semakun besar ukuran perusahaan semakin kecil besaran pengelolaan labanya.

\section{Pengujian Hipotesis 3}

Tabel 5

Statistik Deskriptif Discretionary Accruals

\begin{tabular}{lccccc}
\hline \multicolumn{1}{c}{ Variabel } & $\mathrm{n}$ & Mean & Min. & Max. & SD \\
\hline $\begin{array}{l}\text { Discretionary } \\
\text { Accruals }\end{array}$ & 142 & $-0,07$ juta & -14.341 miliar & 4.890 miliar & 1.657 miliar \\
$\begin{array}{l}\text { Discretionary } \\
\text { Accruals }\end{array}$ & 142 & 644,21 miliar & 1,66 miliar & 14.342 miliar & 1.526 miliar \\
Absolut & & & & & \\
\hline
\end{tabular}

Tabel 6

Analisis Hasil Regresi Linear

$D A_{t}=\alpha_{0}+\alpha_{1}$ Kapitalisasi $_{t}+\mu_{t}$ 


\begin{tabular}{|c|c|c|c|}
\hline \multicolumn{4}{|c|}{ Variabel dependen : Discretionary Accruals } \\
\hline Parameter & Koefisien Regresi & $t$ statistik & Probabilitas $(\rho)$ \\
\hline Intercept & $471.575,3$ & $-1,576$ & 0,119 \\
\hline Kapitalisasi & 7,788 & 2,119 & 0,037 \\
\hline R-squared & 0,064 & & \\
\hline Adjusted R-squared & 0,049 & & \\
\hline
\end{tabular}

Tabel 5 menunjukkan rata-rata discretionary accruals $-0,07$ juta menunjukkan bahwa secara keseluruhan, perusahaan sampel menurunkan laba sebesar 70 ribu rupiah melalui discretionary accruals. Nilai rata-rata yang sangat rendah ini disebabkan oleh adanya lebih banyak perusahaan sampel yang memiliki discretionary accruals negatif sehingga secata total menghasilkan nilai yang sangat rendah. Namun apabila diambil nilai absolut dari discretionary accruals, perusahaan sampel rata-rata memiliki discretionary accruals sebesar 644,21 miliar. Discretionaryaccruals tertinggi sebesar 4.890 miliar atau 4,89 triliun menunjukkan bahwa peningkatan laba melalui discretionary accruals tertinggi sebesar 4,89 triliun rupiah. Discretionary accruals terendah mencapai $\quad-14.342$ miliar.

Tabel 6 menunjukkan nilai adjusted R-Squared sebesar 0,049 yang mempunyai arti bahwa kapitalisasi biaya riset dan pengembangan memiliki kontribusi sebesar 4,9\% terhadap manajemen laba. Nilai probabilitas sebesar 0,037 menunjukkan nilai tersebut signifikan pada $\alpha=5 \%(\rho<0,05)$. Nilai 4,9\% merupakan nilai yang relatif rendah, namun dapat membuktikan bahwa kapitalisasi biaya riset dan pengembangan berpengaruh terhadap tingkat manajemen laba perusahaan. Nilai kontribusi adalah sebesar 4,9\% atau jika dibulatkan menjadi 5\%, sedangkan sisanya sebesar 95\% merupakan faktor lain selain kapitalisasi biaya riset dan pengembangan. Hasil penelitian ini memberikan gambaran bahwa manajemen laba yang dilakukan perusahaan manufaktur di Indonesia, sekitar 5\% terdiri dari kebijakan kapitalisasi biaya riset dan pengembangan.

Hasil penelitian ini mendukung hipotesis 3 dan mendukung penelitian-penelitian sebelumnya seperti Perry\&Grinaker (1994),Bushee (1998),Mande, et al.(2000). Penelitianpenelitian tersebut menunjukkan bahwa kapitalisasi biaya riset dan pengembanganmerupakan salah satu bentuk dari manajemen laba.Singkatnya, hal iniberarti bahwa perusahaanmengkapitalisasibiaya riset dan pengembangan mereka dalamrangka mencapaitargetlaba. Penelitian lain yang juga didukung oleh hasil penelitian ini adalah penelitian Nelson, et al.(2003) yang menemukan bahwa kapitalisasi biaya riset dan pengembangan merupakan salah satu cara yang paling umum dilakukan manajer dalam melakukan perataan laba. 
Hasil koefisien determinasi yang rendah dari penelitian ini menunjukkan rendahnya pengeluaran biaya riset dan pengembangan perusahaan di Indonesia. Berdasarkan hasil penelitian, hanya sebagian kecil perusahaan di Indonesia yang telah melakukan kegiatan Research and Development $(\mathrm{R} \& \mathrm{D})$ dan belum menjadi suatu kewajiban, sehingga pemilihan metode akuntansi atas biaya riset dan pengembanganhanya merupakan kebijakan yang immaterial yang tidak mempengaruhi laba perusahaan secara signifikan (Suharli \& Arisandi, 2009). Dari perusahaan yang menjadi sampel dalam penelitian ini, sebagian besar perusahaan lebih menyukai memilih metode pembebanan atas biaya riset dan pengembangan.

Apabila dibandingkan dengan biaya yang dikeluarkan perusahaan di negara-negara maju seperti Amerika Serikat, Jepang, China, serta negara-negara maju di Eropa, biaya riset dan pengembangan di negara-negara berkembang termasuk di Indonesia sangat jauh tertinggal. Prayoto (2008) dalam Seminar Nasional Dies Natalis UGM ke-45 menyatakan bahwa perbandingan kemampuan IPTEK antara negara kaya dan negara miskin benar-benar membuat kita prihatin. Negara-negara kaya memiliki lebih dari 90\% ilmuwan, bahkan dari segi dana penelitian negara-negara kaya membelanjakan lebih dari 98\% anggaran penelitian. Biaya penelitian dan pengembangan per kapita dari negara-negara berkembang hanyalah sepertigaratus kalinya biaya penelitian dan pengembangan negara-negara maju.Dalam dasawarsa terakhir memang sudah ada tanda-tanda ada sedikit perbaikan tetapi belum cukup untuk merubah gambaran yang memprihatinkan tersebut.

Jumlah ilmuwan per kapita yang berkecimpung dalam kegiatan penelitian dan pengembangan di negara-negara berkembang hanyalah 4\% dari jumlah ilmuwan per kapita di negara-negara maju.Hal ini menunjukkan betapa kuatnya kemampuan IPTEK negara-negara maju dibandingkan dengan negara berkembang.Lebih memprihatinkan lagi bahwa jumlah ilmuwan yang sedikit tersebut, di negara berkembang justru jarang dimanfaatkan sebaikbaiknya.Kalau di negara maju para ilmuwan yang berkecimpung dalam kegiatan penelitian dan pengembangan berjaya dalam menghasilkan penemuan-penemuan baru, dan terlibat langsung serta menyumbang dalam sektor produksi, maka sebagian besar ilmuwan di negara berkembang terbatas peranannya dalam bidang pendidikan dan kadang-kadang dalam bidang pelayanan umum.

Lebih lanjut, Prayoto (2008) menjelaskan bahwa selama PJPT I (1969-1994) perekonomian Indonesia telah tumbuh secara dramatis dengan kecepatan pertumbuhan produk nasional bruto sebesar rata-rata 7\% setiap tahun selama 25 tahun. Pertumbuhan sepesat ini ternyata tercapai dengan makin mengandalkan sektor manufaktur yang pada gilirannya akan makin tergantung pada penerapan IPTEK. Selama tahun-tahun akhir dari 
PJPT I ternyata sektor manufaktur telah tumbuh sebesar $18 \%$ setiap tahun.Walaupun demikian perlu dicatat bahwa pertumbuhan sektor manufaktur ini terutama didukung oleh produk sektor manufaktur yang berteknologi rendah.Bahkan produk sektor manufaktur yang berteknologi tinggi atau menengah sebenarnya masih menunjukkan neraca perdagangan yang negatif.Hal ini menunjukkan produk yang berteknologi tinggi masih belum dapat bersaing di pasaran internasional.

\section{SIMPULAN}

Perusahaan yang memiliki profitabilitas (ROA) lebih rendah dari profitabilitas tahun sebelumnya cenderung untuk mengkapitalisasi biaya riset dan pengembangan untuk dapat mencapai profitabilitas yang setara dengan tahun sebelumnya atau tingkat laba yang merata sehingga perusahaan dapat terhindar dari anggapan investor bahwa perusahaan memiliki risiko yang tinggi. Perusahaan dengan laba yang fluktuatif atau tidak normal dianggap memiliki risiko yang tinggi apabil investor ingin menanamkan modalnya pada perusahaan tersebut.

Perusahaan dengan tingkat utang terhadap total aset (financial leverage) yang tinggi cenderung untuk mengkapitalisasi biaya riset dan pengembangan untuk dapat mencapai target laba yang disyaratkan dalam kontrak utang. Berbeda dengan kondisi pada penelitian sebelumnya di Italia yang memiliki mekanisme dan tingkat pengawasan yang cukup ketat, mekanisme dan pengawasan oleh kreditur di Indonesia cukup longgar. Hal ini kemungkinan disebabkan pengguna laporan keuangan khususnya kreditur tidak melihat manajemen laba sebagai sesuatu yang merugikan.

Kapitalisasi biaya riset dan pengembangan berpegaruh terhadap tingkat manajemen laba, namun hanya mencapai sekitar 5\% dari total manajemen laba yang dilakukan perusahaan. Hal tersebut dikarenakan rendahnya pengeluaran biaya riset dan pengembangan perusahaan di Indonesia. Hanya sebagian kecil perusahaan di Indonesia yang telah melakukan kegiatan riset dan pengembangan(R\&D)dan belum menjadi suatu kewajiban, sehingga pemilihan metode akuntansi atas biaya riset dan pengembanganhanya merupakan kebijakan yang immaterial yang tidak mempengaruhi laba perusahaan secara signifikan. Kapitalisasi biaya riset dan pengembangan terjadi pada semua skala perusahaan baik besar maupun kecil. 
Secara keseluruhan hasil penelitian ini menunjukkan bahwa kapitalisasi biaya riset dan pengembangan mengindikasikan dua motivasi manajemen laba yaitu perataan laba dan untuk menghindari pelanggaran kontrak utang.

\section{DAFTAR PUSTAKA}

Aboody, D., \& Lev, B. 1998. The Value Relevance of Intangibles: The Case of Software Capitalization. Journal of Accounting Research, 36(Supplement 1998), 161-191.

Ballester, M., Garcia-Ayuso, M., \& Livnat, J. 2003. The Economic Value of R\&D Intangible Asset. European Accounting Review 2003, 12(4), 605-633.

Bushee, B. J. 1998. The Influence of Institutional Investors on Myopic R\&D Investment Behavior. The Accounting Review, 73(3), 305-333.

Chaney, P. K., Jeter, D. C., \& Lewis, C. M. 1998. The Use of Accruals in Income Smoothing: A Permanent Earnings Hypothesis. Advances in Quantitative Analysis of Finance and Accounting, 6, 103-135.

Cohen, D. A., \& Zarowin, P. 2010. Accrual-Based and Real Earnings Management Activities Around Seasoned Equity Offerings. Journal of Accounting and Economics, 50(2010), 2-19.

Copeland, R. M. 1968. Income Smoothing. Empirical Research in Accounting. Selected Studies(1968), 101-116.

Daley, L. A., \& Vigeland, R. L. 1983. The Effect of Debt Covenant and the Political Cost on the Choice of Accounting Methods: The Case of Accounting of R\&D Cost. Journal of Accounting and Economics, 5, 195-211.

DeFond, M. L., \& Jimbalvo, J. 1994. Debt Covenant Violation and Manipulation of Accruals. Journal of Accounting and Economics, 17(January 1994), 145-175.

Duke, J. C., \& Hunt, H. G.1990. An Empirical Examination of Debt Covenant Restrictions and Accounting-Related Debt Proxies. Journal of Accounting and Economics, 12(January 1990), 45-63.

Fudenberg, D., \& Tirole, J. 1995. A Theory of Income and Dividend Smoothing Based on Incumbency Rents. Journal oh Political Economy, 103(1), 75-93.

Goel, A. M., \& Thakor, A. V. 2003. Why Do Firms Smooth Earnings? Journal of Business 2003, 76(1), 151-192.

Healy, P. M., Myers, S. C., \& Howe, C. D. 2002. R\&D Accounting and the Tradeoff Between Relevance and Objectivity. Journal of Accounting Research, 40(3), 677-710. 
Jensen, M. C., \& Meckling, W. H. 1976. Theory of the Firm: Managerial Behavior, Agency Costs and Ownership Structure. Journal of Financial Economics, 3(4), 305-360.

Kustono, A. S. 2008. Motivasi Perataan Penghasilan. Jurnal Riset Akuntansi Indonesia, 11(2), 133-157.

Mande, V., File, R. G., \& Kwak, W. 2000. Income Smoothing and Discretionary R\&D Expenditures of Japanese Firms. Contemporary Accounting Research, 17(2), 263-302.

Markarian, G., Pozza, L., \& Prencipe, A. 2008. Capitalization of R\&D and Earnings Management: Evidence from Italian Listed Companies. The International Journal of Accounting, 43, 246-267.

Moses, O. D. 1987. Income Smoothing and Incentives: Empirical Test Using Accounting Changes. The Accounting Review, LXII(2), 358-377.

Nelson, M. W., Elliot, J. A., \& Tarpley, R. L. (2003). How Are Earnings Managed? Examples from Auditors. Accounting Horizons(Supplement 2003), 17-35.

Perry, S., \& Grinaker, R. 1994. Earnings Expectation and Discretionary Research and Development Spending. Accounting Horizons, 8(4), 43-51.

Press, E. G., \& Weintrop, J. B. 1990. Accounting-Based Constraints in Public and Private Debt Agreements. Journal of Accounting and Economics, 12, 65-95.

Scott, W. R. 2009. Financial Accounting Theory (5 ed.). Toronto: Prentice Hall.

Siregar, S. V., \& Utama, S. 2006. Pengaruh Struktur Kepemilikan, Ukuran Perusahaan, dan Praktek Corporate Governance terhadap Pengelolaan Laba (Earnings Management). Jurnal Riset Akuntansi Indonesia, 9(3), 307-326.

Sjarief, J. 2004. Pemilihan Metode Akuntansi atas Biaya Research and Development dan Dampaknya terhadap Price Earnings Ratio. Jurnal Ekonomi dan Bisnis, 4(2), 151161.

Sougiannis, T. 1994. The Accounting Based Valuation of Corporate R\&D. The Accounting Review, 69(1), 44-68.

Suharli, M., \& Arisandi, A. 2009. Pengaruh Pemilihan Metode Akuntansi atas Biaya Research and Development terhadap Price Earnings Ratio. Journal of Applied Finance and Accounting, 1(2), 368-390.

Watts, R. L., \& Zimmerman, J. L. 1990. Positive Accounting Theory: A Ten Year Perspective. The Accounting Review, 65(1), 131-156.

Yusuf, M., \& Soraya. 2004. Faktor-faktor yang Mempengaruhi Praktik Perataan Laba pada Perusahaan Asing dan Non Asing di Indonesia. Jurnal Akuntansi dan Auditing Indonesia, 8(1), 99-125. 
